\title{
Test and validity of the Brand Resonance Model's
}

Luiz Rodrigo Cunha Moura

Doutor em Administração - UFMG.Professor do Curso de Mestrado Profissional de Administração do Centro Universitário UNA

luizrcmoura@gmail.com

Paulo Roberto Ferreira

Especialização em Docência Superior pela Universidade Gama Filho. Especialização em Gestão de Negócios pela Faculdade de Estudos Administrativos de Minas Gerais, FEAD

paulo.vivid@gmail.com

Alessandra Duarte de Oliveira

Mestrado profissional em Administração pelo Centro Universitário UNA. Especialização em Avaliação e Diagnóstico Psicológico pela Pontifícia Universidade Católica de Minas Gerais, PUC Minas alessandra.duarte@gmail.com

Nina Rosa da Silveira Cunha

Doutora em Economia Rural pela Universidade Federal de Viçosa. Professora Titular da Universidade Federal de Viçosa

ninarosaufv@gmail.com

\section{Editor Científico: José Edson Lara}

Organização Comitê Científico

Double Blind Review pelo SEER/OJS

Recebido em 06.08.2018

Aprovado em 25.10.2018

\section{(c) () (9)}

Este trabalho foi licenciado com uma Licença Creative Commons - Atribuição - Não Comercial 3.0 Brasil 


\begin{abstract}
This study has the purpose to test and validate the Brand Resonance Model which is represented by a pyramid that contains cause and effect relationships between the constructs related to the brand (salience, image, performance, feeling, judgment and resonance), whose ultimate goal is to represent brand equity. Part of the research was carried out by a survey applied to hotel guests, at the end obtaining 302 questionnaires. Procedures were performed for data treatment, the constructs unidimensionality and reliability, convergent validity, discriminant validity and nomological validity. The results indicate that the Brand Resonance Model has nomological validity, since all the theoretical relations between the constructs were statistically significant. In terms of outcome the rational path - formed by performance and judgment - has a greater impact on brand resonance than the emotional path - image and feeling. The $\mathrm{R}^{2}$ of brands' resonance, the value obtained was $83 \%$.
\end{abstract}

Keywords: Brand Resonance. Brand Resonance Pyramid. Brand Equity. Brand management. Validation and Testing of a Model.

\title{
Teste e validação do Modelo de Ressonância de marca
}

\section{Resumo}

Esse trabalho tem por objetivo testar e validar o Modelo de Ressonância de Marca que é representado por uma pirâmide que contém as relações de causa e efeito entre construtos relacionados com a marca (saliência, imagem, performance, sentiment, julgamento e ressonância), cujo objetivo é representar o brand equity. A coleta de dados ocorreu através de um levantamento com os hóspedes de um hotel obtendo-se 302 questionários. A análise foi realizada por meio do tratamento dos dados, verificação da unidmensionalidade e confiabilidade dos construtos, validade convergente, validade discriminante e validade nomológica. Os resultados indicam que o Modelo de Ressonância de Marca possui validade nomológica, pois, todas as relações entre os construtos são estatisticamente significativas. $\mathrm{O}$ caminho racional - formado pela performance e julgamento - apresenta um maior impacto na ressonância da marca do que o caminho emocional - imagem e sentimento. Foi obtido um valor de $83 \%$ para o $\mathrm{R}^{2}$ da ressonância da marca.

Palavras-Chave: Ressonância de Marca. Pirâmide de Ressonância de Marca. Brand Equity. Gerenciamento de Marca. Validação e Teste de um Modelo.

\section{Prueba y validación del Modelo de Resonancia de Marca}

\section{Resumen}

Este trabajo tiene por objetivo probar y validar el Modelo de Resonancia de Marca que está representado por una pirámide que contiene las relaciones de causa y efecto entre constructos relacionados con la marca (saliente, imagen, performance, sentimiento, juicio y resonancia), cuyo objetivo es representar el brand equity. La recolección de datos ocurrió a través de un levantamiento con los huéspedes de un hotel obteniendo 302 cuestionarios. El análisis fue 
realizado por medio del tratamiento de los datos, verificación de la unidmensionalidad y confiabilidad de los constructos, validez convergente, validez discriminante y validez nomológica. Los resultados indican que el Modelo de Resonancia de Marca tiene validez nominal, pues todas las relaciones entre los constructos son estadísticamente significativas. El camino racional -formado por la performance y el juicio- presenta un mayor impacto en la resonancia de la marca que el camino emocional - imagen y sentimiento. Se obtuvo un valor del $83 \%$ para el $\mathrm{R}^{2}$ de la resonancia de la marca.

Palabras Clave: Resonancia de Marca. Pirámide de Resonancia de Marca. Brand Equity. Gestión de marcas. Validación y prueba de un modelo.

\section{Introduction}

Brand equity is one of the main research topics today (Bastos, Moura \& Christino, 2014; Aziz \& Yasin, 2010), being considered very important in the services sector, because, unlike products that can be tangibilized through packaging, labeling and products physical characteristics, services are intangible and strong brand equity is an important aspect of brand awareness in the service sector (Verma; 2012, Aziz \& Yasin, 2010).

Brand equity is one of the main responsible for customer loyalty and the creation of this relationship is a long-term process formed by several components, which must be identified and described in terms of their importance for the formation of a strong brand equity. These components and their interrelations form the models (Moura et al., 2017; Raut, 2015).

This work aims to test and validate the Brand Resonance Model developed by Keller (1993), as well as to verify the scales validity of the scales used to measure the six components of the Brand Resonance Model - and consequently the brand resonance - and also measure the explained variance of the brands' resonance (bond) with the Brazilian Hotels' guests.

Recent studies have sought to create a scale that is reliable and valid to measure brand resonance, which is considered a gap of current knowledge (Raut, 2015). In this work specifically, scales based on recent work are used to test the psychometric characteristics of these scales, that is, to test and create valid and reliable measures for the measurement of the brand resonance.

It is important to be emphasized that the test and validation of theoretical models in several countries and with different cultures is an indispensable theoretical contribution, since it allows to reach the external validity and the generalization of results for other populations or it helps to define the limits and possibilities of theories generalization. All these factors lead to a knowledge higher level and science advancement (Rosenberger III, 2007). 
Also in academic terms, it is described the need to carry out further studies on the Brand Resonance Model in the service area and in different sectors such as hotels, travel agencies, restaurants and others. This will allow the results' cross-validation, besides the possibility of results' generalization (Gautam \& Kumar, 2012; Aziz \& Yasin, 2010). Another point is the development of brand equity and brand relationship in developing countries is still incipient and will differ from studies in developed countries considering factors such as economics, culture, demographics, social groups, and so on (Raut, 2015).

In practical terms, it is important for service companies to create strong brands due to the current level of competition in the market (Bastos, Moura \& Christino, 2014; Farhana \& Islam, 2012), generating an increase on companies' competitiveness (Adrian, 2014), as well as a better financial performance (Sandhe, 2016). Relationships creation between companies and their consumers through brands is a key issue for brand managers (Raut, 2015; Bastos, Moura \& Christino, 2014).

\section{Brand resonance model}

The Brand Resonance Model is based on consumers' perceptions, beliefs and attitudes to measure brand strength. In order to achieve the desired results, marketing managers must decide what and how consumers should know about the brand, what are their differentials and associations, the desired responses and the reasons why consumers should be brand loyalists (Markus \& Fallmyr, 2014; Raut, 2015; Moura et al., 2017) and what will be the experience with the brand (Tri, 2014). One can identify the strongest brands according to their consumers, but also identify the brands that have problems (Farhana \& Islam, 2012).

One of the major contributions of the Brand Resonance Pyramid in comparison with Keller's original CBBE (consumer based brand equity) Model is the inclusion of the brand overhang block o the pyramids' base. Sailing has become much more important, since it is no longer just brand awareness, but also brand recall and recognition on the most diverse consumer occasions (Keller, 2016).

The process of building the brand equity - known as the Brand Resonant Model - involves the execution of four steps (Keller, 2001; Ahrens, 2016; Tsai, Lin \& Li, 2014; Farhana \& Islam, 2012; Verma, 2012; Yasin, 2010), and the next step can only be performed adequately if the previous step reaches its objectives (Markus \& Fallmyr, 2014). For the brand to reach its 
resonance stage, managers need to be able to generate cognitive assessments and emotional reactions by consumers towards the brand through the creation of a unique brand identity and positive associations hard to be copied by other brands (Keller, 2001; Markus \& Fallmyr, 2014). In sum, the Brand Resonance Model is based on what it represents on consumers' minds (Tri, 2014; Moura et al., 2017).

The first step is to create consumer identification and recognition of the brand, that is, a deep and wide awareness coupled with brand recall. Creating a meaning for the brand is the second step, in this case, brand associations and characterizations are elaborated, both in terms of rational and tangible aspects related to brand performance, as well as in emotional terms and to intangible aspects related to brand image (Keller, 2001; Storm, 2015; Márkus \& Fallmyr, 2014; Tsai, Lin \& Li, 2014).

The third step is represented by the generation of positive responses from consumers to the brand, through judgments and feelings on consumers' part (Keller, 2001; Adrian, 2014; Aziz \& Yasmin, 2010). In the case of brand judgments, it represents a general cognitive assessment of the brands' credibility, superiority, quality and other functional and symbolic aspects compared to its competitors (Raut, 2015) and in emotional responses, feelings represent the emotions and sensations that the brand generates in the consumer, and may represent the level of identification between those consumers' and the brand (Keller, 2001; Baird, 2015; Tri, 2014).

From the consumers' positive responses to the brand, the fourth step is the goal of achieving a strong relationship between the brand and its consumers (Adrian, 2014) in terms of loyalty through consecutives purchases and other behaviors such as positive word of mouth and the number of products increase and services purchased related to the brand. This involves the highest level of relationship between the brand and its customers, in which brand resonance exists (Keller, 2001; Márkus \& Fallmyr, 2014; Yasin \& Aziz, 2010), and may also represent the sacrifices' level for customer to consume the brand (Raut, 2015).

As these four steps' execution consequences, one has the creation of six blocks that will sustain the Brand Resonance Pyramid, which are the salience of the brand, brand performance, brand's image, brand's judgment, the feeling in relation to the brand and the brands' resonance (Keller, 2001; Storm, 2015; Markus \& Fallmyr, 2014; Tsai, Lin \& Li, 2014; Gautam \& Kumar, 2012) 


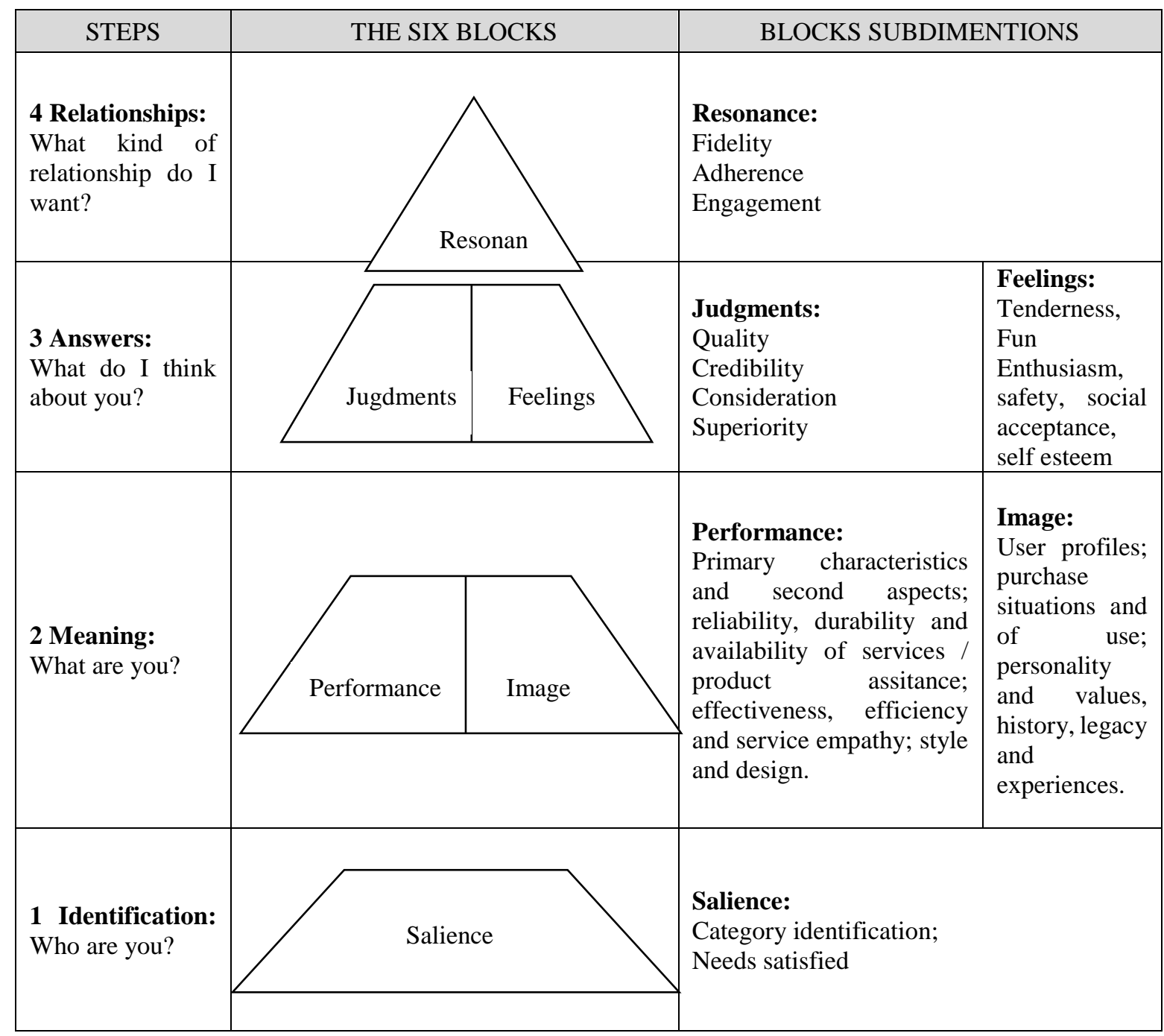

\section{Figure 1}

Brand Resonance Pyramid and it's sustainable blocks Source: Adapted by Keller (2016; 2001).

The Brand Resonance Pyramid is formed by two paths: the rational path - located on the pyramids' left side - and the emotional path - located on the pyramids' direct side and both lead to the top of the pyramid, so the brands' resonance (Storm, 2015; Tri, 2014; Adrian, 2014). In order for brand resonance to occur, both paths must be traversed by the brand, both emotionally and rationally (Keller, 2016).

In regarding to the Brand Resonance Pyramid is that it helps managers to more easily identify the items to be managed to achieve brand equity (Adrian, 2014) and to achieve a strong brand resonance or strong brand equity - according to the steps already described - involves the 
bottom-up path in the pyramid (Markus \& Fallmyr, 2014), therefore the main goal is to reach the top of the pyramid - to achieve brand resonance (Tri, 2014).

The Brand Resonance Model is a structured model aimed at managing the brand equity value through steps formed by the six blocks of the Brand Resonance Pyramid (Adrian, 2014), helping marketers to make better decisions on trademarks (Choudhury \& Kakati, 2014).

In addition, a brand with strong brand equity has consumer preference, better marketing communications, lower costs, brand licensing possibilities, greater share value return, ease of brand extensions, and dealing more easily with distribution channels (Baird, 2015).

The overhang is the Brand Pyramids' first block (Keller, 2001; Baird, 2015) and is related to consumer brand awareness, helping people to recognize or remember brand more easily, (Keller, 1993, 2001; Sandhe, 2016; Márkus \& Fallmyr, 2014), as well as consumers' propensity to remember the brand in purchasing situations (Raut, 2015). Finally, it describes the strength of brand recall and recognition (Tri, 2014), brands' strength on consumers' mind (Raut, 2015) or how the brand can come to the consumers' head in specific situations (Adrian, 2014).

It is possible to see that the salience of the brand generates competitive advantages for companies (Tri, 2014), such as future purchase intention, the product or services' value perception, positive word of mouth advertising, loyalty, remembrance of marketing communication and others alike (Adrian, 2014). In situations where there is a low purchase involvement from consumer or when he or she is unaware of other brands, the brand overhang is sufficient to make the purchase (Márkus \& Fallmyr, 2014).

From the Brand Resonance Pyramid and the concepts described, hypotheses were created:

Hypothesis 1: Brand saliency has a positive effect on brand performance.

Hypothesis 2: Brand saliency has a positive effect on brand image.

Brand performance is another block of the brand Resonance Pyramid is directly related to the ability of the product or service to meet customer expectations. These products and services are very important because they are the point of reference when consumers think about the brand, hear something about it or even when the company wants to communicate something about the brand to consumers (Keller, 2001; Sandhe, 2016; Raut, 2015; Choudhury \& Kakati, 2014; Tri, 2014). Thus, products and services should always at least meet consumer expectations through brand experience (Keller, 2001; Raut, 2015). 
Hypothesis 3: Brand performance has a positive effect on brand judgment.

The brand image is related to the most intangible aspects of the brand (Baird, 2015, Adrian, 2014; Márkus \& Fallmyr, 2014), with its extrinsic aspects (Choudhury \& Kakati, 2014; Sandhe, 2016) and represents all perceptions (Keller, 1993), often learned over time through brand experience (Aaker, 1991; Raut, 2015), through marketing communications and through word of mouth (Adrian, 2014). It is the abstract and non-rational perception of what the brand is (Choudhury \& Kakati, 2014).

Hypothesis 4: Brand image has a positive effect on brand feeling.

The brands' judgment is formed by the consumers personal opinions regarding the brand, which consider all the images and all the associations related to the brand to create a general evaluation of it (Keller, 2001; Baird, 2015; Raut, 2015; Márkus \& Fallmyr 2014; Adrian, 2014).

In terms of consumer behavior, when there are many choice options, brand credibility can be considered as an important differential for the company and a simplification of the consumer purchasing decision process (Tri, 2014).

Hypothesis 5: Brand judgment has a positive effect on brand resonance.

Brand sentiment is also one of the blocks of the Brand Resonance Pyramid and is related to the reactions and emotional responses of consumers to the brand (Keller, 2001; Sandhe, 2016), as well as being associated with the social aspects of the brand (Raut, 2015), being considered as an irrational evaluation of the brand from its present image in the minds of consumers (Tri, 2014), which can be positive or negative (Baird, 2015; Markus \& Fallmyr, 2014), of high or low intensity (Keller, 2001; Adrian, 2014). It is to be considered that brand feelings are easier to be affected by emotional and social factors than brand judgment (Tri, 2014).

Hypothesis 6: Brand feeling has a positive effect on brand resonance. 
Resonance is the last block of the Brand Resonance Pyramid and represents the relationship and level of identification between the brand and its consumers (Keller, 2001, Sandhe, 2016; Baird, 2015; Choudhury \& Kakati, 2014, Adrian, 2014), making brand clients loyal and actively participating in its relationship (Markus \& Fallmyr, 2014).

Brand resonance has two dimensions (the intensity of the psychological bond and the type of consumer behavior generated by that link), which are divided into four categories (behavioral loyalty, attitudinal relationship, community perception, engagement with the brand) (Keller, 2001; Sandhe, 2016; Baird, 2015; Adrian, 2014; Markus \& Fallmyr; 2014). All four of these items have already been studied separately in marketing, but Keller (2001) was the first author to work with all of them together (Baird, 2015). In order to achieve brand resonance, the other five previous blocks must also have been adequately achieved (Baird, 2015).

\section{Hypothetical model}

From the foregoing and using the Brand Resonance Model, the hypothetical model was elaborated, represented by Figure 2 below.

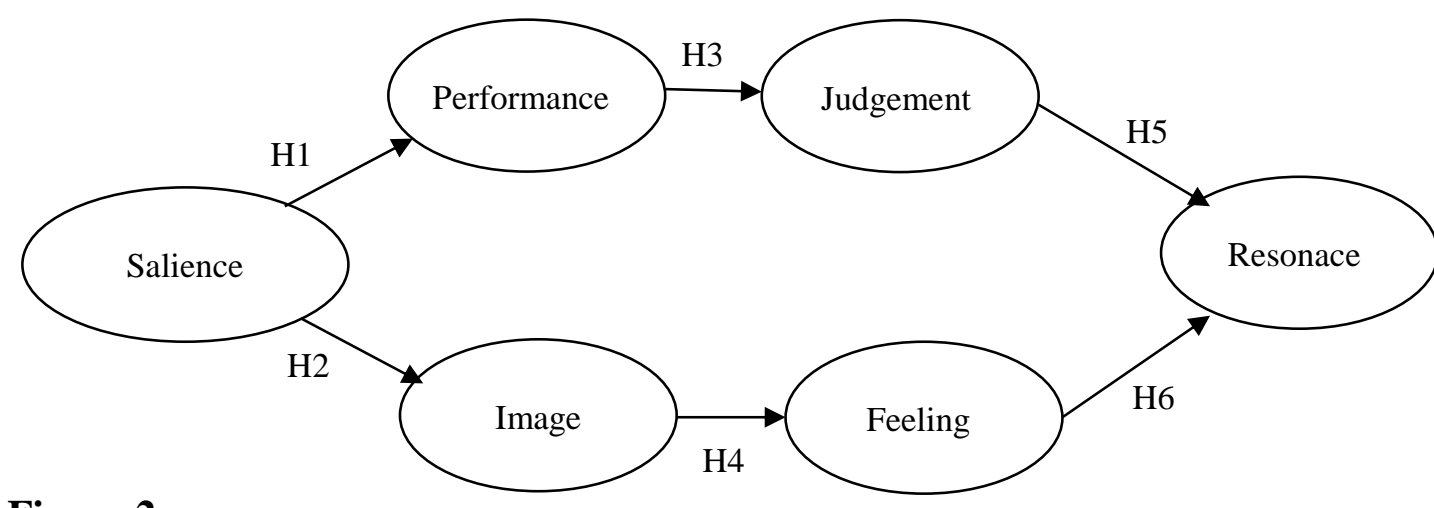

\section{Figure 2}

Hypothetical Model

Source: elaborated by authors.

\section{Methodology}

In order to correctly carry out the research, it was decided that the target audience of the research were the Gran Lord Hotel guests, which has the information to achieve the research objective, that is, to test the Brand Resonance Model. 
The data collection instrument was elaborated considering the Brand Resonance Model, both in theoretical terms (Keller, 2016, 1993) and in empirical terms from previous studies, carried out mainly in the banking sector (Raut, 2015; Choudhury \& Kakati, 2014; Farhana \& Islam, 2012; Aziz \& Yasin, 2010; Yasin \& Aziz, 2010), deciding to do the survey.

The questionnaire presented as anchors the terms "strongly disagree" and "fully agree", using a scale ranging from " 0 " to "10". The scale used is classified as an interval, presenting eleven points in which there is the possibility to register more precisely and in a more detailed way the variations of the interviewees' opinions (Nunnaly \& Bernstein, 1994; Fornell et al., 1996).

After the instrument elaboration of data collection - the questionnaire - a pre-test was carried out with the surveys' target audience - Gran Lord Hotel guests - with the intent to verify the possible problems and errs the questionnaire could present. Thirty questionnaires were applied to the hotel guests and the results were quite satisfactory and no changes had to be made to the questionnaire.

The process of data collection took place inside the hotel itself. At first, the number of questionnaires collected was very small. Guests had no patience or interest in participating in the survey. Later, the questionnaire was applied in the hotel restaurant and while the guests waited for their meal to be ready, they answered the questionnaire because they had time available. It should also be considered that a filter question was included in which it was asked if the respondent was a hotel guest or if he was only having lunch or dinner. In the latter case, we thanked the intention to participate in the respondent - but as the research is about the brand equity and brand resonance of the guests of the Gran Lord Hotel - so the questionnaire wasn't applied.

Regarding to the samples' size, it is necessary to emphasize the existence of at least 10 elements in the sample for each variable to be considered in the multivariable statistical techniques, mainly in relation to the modeling of structural equations. Thus, the number of 302 questionnaires obtained and that compose the sample was considered satisfactory, even considering the disposal to be made of some sample cases from the data processing activities. 


\section{Data analysis}

Data analysis involved a number of activities over time. The first activity was data treatment based on the identification of the multivariate outliers, discarding of the questionnaires with a high number of missing data, withdrawal of the cases in which the interviewees presented lack of coherence regarding the identical questions in the questionnaire and verification of the samples' normal distribution. Next, we carried out exploratory factor analyzes for all six constructs, as well as the calculation of the Cronbach Alpha (scales reliability), as well as the verification of the convergent validity and discriminant validity verification.

Finally, the nomological validity of the Brand Resonance Model was tested through the modeling of structural equations.

\subsection{Sample characteristics and data treatment}

The first activity related to the data treatment was the distance calculation $\mathrm{D}^{2}$ of Mahalanobis and its subsequent comparison with the test value of $X^{2}$. From this procedure it is possible to identify the multivariate outliers present in the sample (Hair et al., 2009). As the Brand Resonance Model present in this research has a total of twenty-two variables, the value of the $X^{2}$ Test (for 22 degrees of freedom and significance of 0.001) is 48,268. All sample elements that presented Mahalanobis $\mathrm{D}^{2}$ distance values above 48,268 were considered outliers and removed from the sample. At the end of the procedure, thirty sample elements were removed.

In addition, all cases that had more than $20 \%$ of missing data were also taken from the sample and since the questionnaire had two identical questions, all cases where the difference was greater than two - the scaling ranged from 0 to 10 - between the two responses to these identical questions were also eliminated. In the latter case, twenty-two cases were taken from the sample. The final sample consisted of 225 elements, with a slightly higher ratio of ten sample elements for each of the twenty-two questions present in the data collection instrument and related to the Brand Resonance Model.

The next activity related to the data treatment was the verification if the sample had a normal distribution. For this, the Kolgomorov-Smirnov Test (Malhotra, 2011) was performed. As a result, no variables of the questionnaire had normal distribution and therefore, the 
statistical methods used in the data analysis should be robust for samples that do not have normal distribution.

The sample characteristics, which consists mainly of men with $59.1 \%$ of the total, and the largest group of respondents is between 36 and 50 years old (44\% of the total). In addition, people in families that earn monthly between two and five minimum wages make up the largest group in this category (38.2\%). Finally, regarding to the motive of the trip, an almost identical division was identified between those who traveled on business $(51.6 \%)$ and those who traveled on leisure $(48.4 \%)$.

\subsection{Unidimensionality, reliability, convergent validity and discriminating validity}

In this step, the first one is to verify that the items or questions that represent each of the six dimensions present in the model actually refer to only one dimension or factor. This verification occurs through exploratory factorial analyzes (EFAs) for each of the constructs. However, it must also be considered that for the calculation of each of the EFAs it is necessary that each of the three assumptions described below are met.

The first assumption describes that there must be significantly positive correlations between all items that form a construct. The results obtained indicate that all items of all constructs are significant among themselves. In addition, there is another assumption related to the suitability test of the KMO (Kaiser-Meyer-Olkin) sample, which should results in values of at least 0.60 are considered acceptable values. The results shown in Table 1 show this assumption being met (Malhotra, 2011; Hair et al., 2009). The third assumption is related to Bartlett's Sphericity Test, which must present a significant correlation at the 95\% level (Morgan \& Griego, 1998). The results in Table 1 also indicate that this assumption was met.

In addition, Table 1 also presents the Cronbach Alpha values, which is used to verify the reliability of each of the scales used to measure each of the six constructs present in the Brand Resonance Model. The Cronbach's Alpha value ranges from 0 to 1 and should present values above 0.60 for scales being tested for the first time and values above 0.70 for previously validated scales are considered adequate values (Malhotra, 2011; Hair et al., 2009).

The results obtained can be considered very well. All six values for Cronbach's Alpha presented values above 0.90 , which means that all six scales used to measure constructs are reliable. 
Luiz Rodrigo Cunha Moura, Paulo Roberto Ferreira, Alessandra Duarte de Oliveira, Nina Rosa da Silveira Cunha

\section{Table 1}

Dimensionality values, reliability and components validity of the brand resonance model

\begin{tabular}{|c|c|c|c|}
\hline Construct & Items Description & Component & $\begin{array}{c}\text { Standardized } \\
\text { Factorial Load }\end{array}$ \\
\hline \multirow{3}{*}{$\begin{array}{l}\text { Image } \\
\text { V.E. }=91,49 \% \\
\text { KMO }=0,752 \\
\text { E.B. }=715,04 \\
\text { Sig. }=0,000 \\
\text { A.C. }=0,953 \\
\text { A.V.E. }=0,874 \\
\text { C.R. }=0,976\end{array}$} & IMAG1 - The Gran Lord Hotel appearance is attractive. & 0,949 & 0,910 \\
\hline & IMAG2 - The Gran Lord Hotel has a good image & 0,971 & 0,980 \\
\hline & $\begin{array}{l}\text { IMAG3 - People have a positive image of the Gran Lord } \\
\text { Hotel. }\end{array}$ & 0,949 & 0,913 \\
\hline \multirow{4}{*}{$\begin{array}{l}\text { Judgment } \\
\text { V.E. }=9,73 \% \\
\text { KMO }=0,863 \\
\text { E.B. }=.103,8 \\
\text { Sig. }=0,000 \\
\text { A.C. }=0,962 \\
\text { A.V.E. }=0,867 \\
\text { C.R. }=0,980\end{array}$} & $\begin{array}{l}\text { JUDG1 - My overall opinion about the Gran Lord Hotel is } \\
\text { good. }\end{array}$ & 0,946 & 0,928 \\
\hline & JUDG2 - I am pleased to be a client of the Gran Lord Hotel & 0,968 & 0,973 \\
\hline & $\begin{array}{l}\text { JUDG3 - The Gran Lord Hotel is superior in comparison } \\
\text { with others hotels by the same category in Pará de Minas }\end{array}$ & 0,958 & 0,949 \\
\hline & JUDG4 - The Gran Lord Hotels' quality is good. & 0,916 & 0,870 \\
\hline \multirow{3}{*}{$\begin{array}{l}\text { Salience } \\
\text { V.E. }=90,24 \% \\
\text { KMO }=0,765 \\
\text { E.B. }=641,49 \\
\text { Sig. }=0,000 \\
\text { A.C. }=0,946 \\
\text { A.V.E. }=0,854 \\
\text { C.R. }=0,971 \\
\end{array}$} & $\begin{array}{l}\text { SAL1 - I can recognize the Grand Lord Hotels' brand better } \\
\text { than other Hotels. }\end{array}$ & 0,945 & 0,910 \\
\hline & $\begin{array}{l}\text { SAL2 - I can easily remember the brand and logo of Gran } \\
\text { Lord Hotel. }\end{array}$ & 0,961 & 0,956 \\
\hline & SAL3 - The Gran Lord brand is easy to be recognized. & 0,944 & 0,906 \\
\hline \multirow{4}{*}{$\begin{array}{l}\text { Performance } \\
\text { V.E. }=88,43 \% \\
\text { KMO }=0,844 \\
\text { E.B. }=1031,82 \\
\text { Sig. }=0,000 \\
\text { A.C. }=0,956 \\
\text { A.V.E. }=0,866 \\
\text { C.R. }=0,980\end{array}$} & $\begin{array}{l}\text { PERF1 - Comparing to the same category Hotels in Pará de } \\
\text { Minas, the Gran Lord offers the best services. }\end{array}$ & 0,911 & 0,886 \\
\hline & PERF2 - The Gran Lord Hotel meets my expectations. & 0,960 & 0,956 \\
\hline & PERF3 - The Gran Lord Hotel services are efficient. & 0,957 & 0,956 \\
\hline & $\begin{array}{l}\text { PERF4 - The Gran Lord Hotel supply my basic needs as a } \\
\text { client. }\end{array}$ & 0,933 & 0,922 \\
\hline \multirow{5}{*}{$\begin{array}{l}\text { Resonance } \\
\text { V.E. }=85,91 \% \\
\text { KMO }=0,861 \\
\text { E.B. }=1314,39 \\
\text { Sig. }=0,000 \\
\text { A.C. }=0,959 \\
\text { A.V.E. }=0,885 \\
\text { C.R. }=0,985\end{array}$} & $\begin{array}{l}\text { RES1 - Even though there is another cheaper hotel in Pará } \\
\text { de Minas, I prefer to stay at the Gran Lord Hotel. }\end{array}$ & 0,922 & 0,931 \\
\hline & $\begin{array}{l}\text { RES2 - Next time when I come to Pará de Minas I intent to } \\
\text { stay at the Gran Lord Hotel. }\end{array}$ & 0,931 & 0,958 \\
\hline & $\begin{array}{l}\text { RES3 - I am loyal to the Gran Lord Hotel when I need to go } \\
\text { to Pará de Minas. }\end{array}$ & 0,930 & 0,921 \\
\hline & $\begin{array}{l}\text { RES4 - In Pará de Minas, the Gran Lord Hotel is my first } \\
\text { option. }\end{array}$ & 0,932 & 0,938 \\
\hline & $\begin{array}{l}\text { RES5 - If I have good financial conditions I stay at the Gran } \\
\text { Lord Hotel. }\end{array}$ & 0,919 & 0,915 \\
\hline \multirow{3}{*}{$\begin{array}{l}\text { Feeling } \\
\text { V.E. }=93,37 \% \\
\text { KMO }=0,776 \\
\text { E.B. }=805,58 \\
\text { Sig. }=0,000 \\
\text { A.C. }=0,964 \\
\text { A.V.E. }=0,901 \\
\text { C.R. }=0,982\end{array}$} & FEEL1 - I feel good when I stay at the Gran Lord Hotel. & 0,960 & 0,932 \\
\hline & FEEL2 - The Gran Lord Hotel makes me happy. & 0,972 & 0,967 \\
\hline & FEEL3 - Stay at the Gran Lord Hotel is a pleasure. & 0,966 & 0,948 \\
\hline
\end{tabular}

Notes: 1) V.E. is the explained variance by the factor. 2) KMO is the value of KMO. 3) E.B. is the value of Bartlett's test of stiffness. 4) Sig. is Bartletts' statistical sphericity test. 5) A.C. is Alpha de Cronbach value. 6) A.V.E. is the mean variance extracted. 7) C.R. is the composite reliability. 8) Pará de Minas is the city where Gran Lord Hotel is situated.

Source: research data 
Another analysis is related to the convergent validity, which is verified through the measurement of the Composite Reliability (CR) and the Average Variance Extracted (AVE) values. In order for the convergent validity to be confirmed, it is necessary that the CR value be at least 0.70 and the AVE value be at least 0.5 (Hair et al., 2009). Analyzing Table 1, the constructs that form the Model of Resonance of the brand studied have convergent validity.

Besides the convergent validity, it is also necessary to verify the discriminant validity for all the constructs that form the tested model. To verify the discriminant validity, it is necessary to compare the results of the correlations of all the constructs with the square root values of all AVEs (Hair et al., 2009). The results are presented in the Table 2, in which the diagonal matrix - represented by the bold values - contains the square root values of the AVEs of the construct and the values in italic and underline represent those relations between the constructs that do not have discriminant validity.

Table 2

Correlations of all the constructs and square root values of the AVEs

\begin{tabular}{l|c|c|c|c|c|c}
\hline CONSTRUCTS & Image & Judgment & Salience & Performance & Resonance & Feeling \\
\hline Image & $\mathbf{0 . 9 3 5}$ & & & & & \\
\hline Jugdment & $\underline{0.955}$ & $\mathbf{0 . 9 3 1}$ & & & & \\
\hline Salience & 0.700 & 0.711 & $\mathbf{0 . 9 2 4}$ & & & \\
\hline Performance & 0.914 & 0.853 & 0.923 & $\mathbf{0 . 9 3 1}$ & & \\
\hline Resonance & 0.847 & 0.881 & 0.697 & 0.848 & $\mathbf{0 . 9 4 1}$ & \\
\hline Feeling & 0.864 & $\underline{0.955}$ & 0.707 & 0.804 & 0.874 & $\mathbf{0 . 9 4 9}$ \\
\hline
\end{tabular}

Source: research data.

When analyzing Table 2 , of the 15 possible combinations total, only two did not present values that were consistent with the discriminant validity, that is, the correlation value between the two constructs was greater than the square root value of the AVE. These relationships are between image and judgment; and feeling and judgment (underlined and italic values).

This means that judgment has a high level of redundancy with image and feeling, both of which are on the emotional axis and the image is a predecessor of feeling. However, this fact does not make it impossible to verify the Brand Resonance Models' nomological validity, since judgment is a predecessor of brand resonance, just as feeling is also a brands' resonance predecessor. In addition, several studies, despite studying the Brand Resonance Model, did not perform the procedures of convergent validity, discriminant validity and nomological validity (Sandhe, 2016; Gautam \& Kumar, 2012; Verma, 2012; Farhana \& Yslam, 2012; Aziz \& 
Yasmin, 2010). These studies analysis was based on only a linear regression in which the dependent variable was represented by the brand resonance and the independent variables represented by the other constructs - salience, image, performance, feeling and judgment besides verification of the scales reliability, of exploratory factorial analysis, as well as correlations between these constructs. Only Rauts' work (2015) presented the analysis of the convergent and discriminant validity, reaching adequate values.

\subsection{Nominal validity}

This studies' main purpose is to verify the nomological validity of the Brand Resonance Model and for this, in addition to all previous steps, it is also necessary to perform a structural equation modeling (SEM) to verify if the relations recommended in the theory is reached by empirical data means, which was calculated from the generalized least squares estimation method (GLS), considering that the sample has no normal distribution. The results are shown in Figure 3.

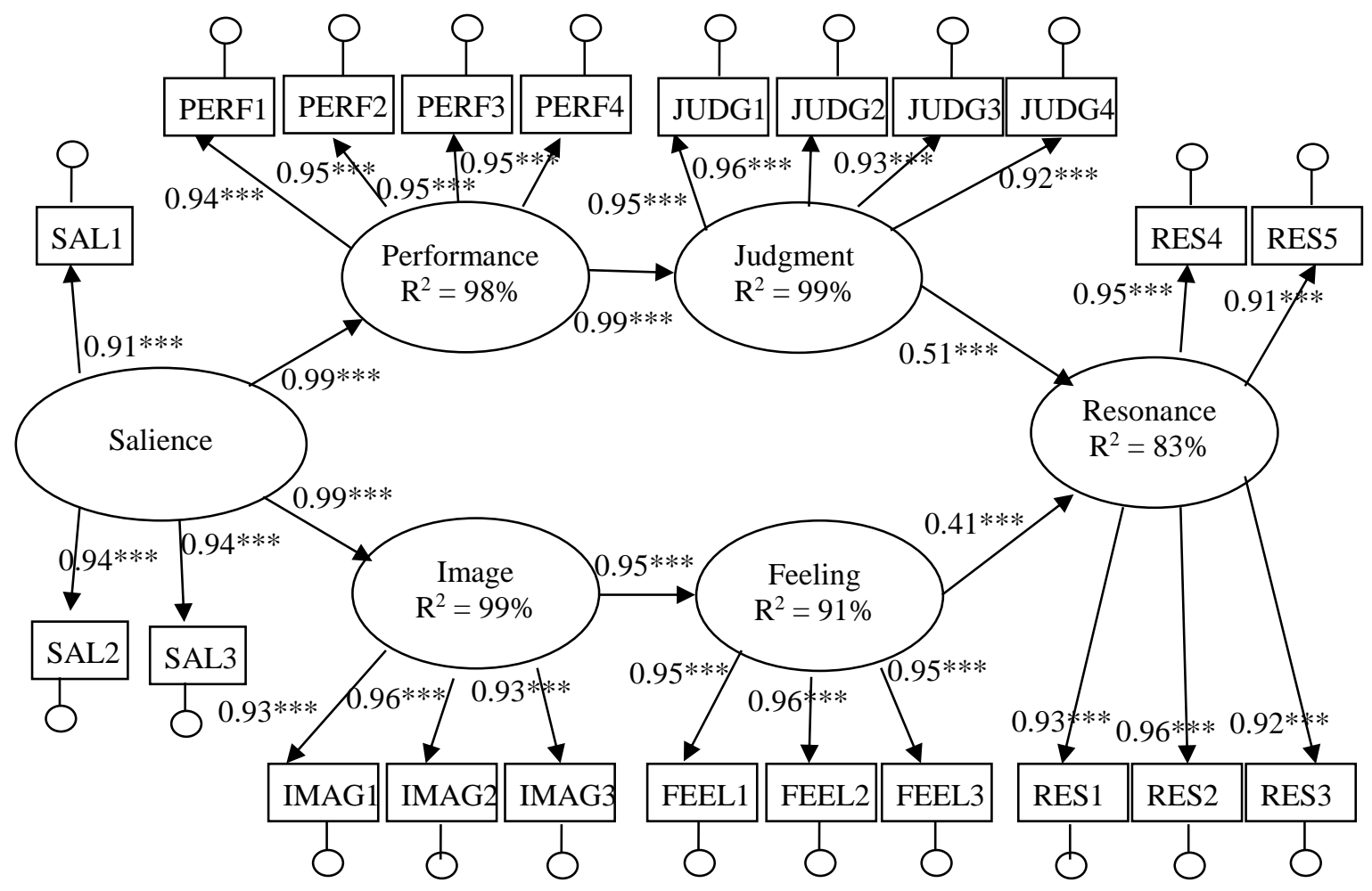

Figure 3

Brand Resonance Model standard load values

Note: $* * *$ significant 0.01

Source: research data. 
From the data shown in Figure 3, it is possible to conclude that the Brand Resonance Model has nomological validity. In addition, all relations between the constructs described in the theory presented statistical significance.

Comparing the results obtained with some other studies, in the same way as with Verma (2012), the rational path (performance and judgment) are more important than the image and the feelings in the prediction of the brand resonance. In addition, in Aziz and Yasmim (2010) and Farhana and Islam (2012) the feeling is as important in influence terms on the brand resonance as performance and judgment, which diverges from the obtained results. In Gautam and Kumar's paper (2012), judgment and feeling are the items that most impact on brand resonance and in Sandhe (2016) the feeling is more than twice as important as judgment and performance in resonance branded. Finally, in the case of a greater involvement product (cellular phone), the feeling and judgment are of similar importance, but when analyzing the product results of low involvement (soft drink), the feeling becomes more important than the judgment (Raut, 2015).

Figure 2 shows that the rational path influences brand resonance more strongly than the emotional path, but in terms of the direct and indirect influence of the constructs through the paths, it is verified that the image and the performance are fundamental for the brand resonance formation. Furthermore, through indirect influence, it is found that the projection has an enormous influence on the brand resonance formation, mainly through the rational path.

The $\mathrm{R}^{2}$ values were also quite significant. Regarding the image, its explained variance was $99 \%$, in the case of performance the explained variance was $98 \%$. The performance influenced the judgment, which presented a $\mathrm{R}^{2}$ of $99 \%$. The feeling is influenced by the image and its $\mathrm{R}^{2}$ was $91 \%$. Finally, the resonance of the brand or its bond with hotel guests was $83 \%$, that is, $83 \%$ of the intention to stay as hotel guests in the future can be explained by the other five elements of the Brand Resonance Model.

This $83 \%$ value for the explained variance is above the values obtained for the brand resonance present in other studies, but it was calculated by means of a linear regression, in which the brand resonance is the dependent variable and the other five dimensions (salience, image, performance, feeling, and judgment) are the independent variables. The results obtained for $\mathrm{R}^{2}$ were $77.4 \%$ (Sandhe, 2016), 75.9\% (Farhana \& Islam, 2012), 65.7\% (Verma, 2012), 65.6\% (Gautam \& Kumar, 2012) and 62.5\% (Aziz \& Yasin, 2010).

The verification of the assumptions is described on Table 3. 
Table 3

Verification of the Research Hypotheses.

\begin{tabular}{l|c}
\hline \multicolumn{1}{c|}{ HYPOTHESES } & RESULTS \\
\hline H1: Brand salience has a positive effect on the brand performance & Supported \\
\hline H2 Brand salience has a positive effect on the brand image & Supported \\
\hline H3: Brand performance has a positive effect on brand Judgment & Supported \\
\hline H4: Brand image has a positive effect on brand feeling & Supported \\
\hline H5: Brand judgment has a positive effect on brand resonance & Supported \\
\hline H6: Brand feeling has a positive effect on brand resonance & Supported \\
\hline
\end{tabular}

Source: search data

In the case of SEM, in addition to the values considered in the relationships between the constructs and the factorial load of the items that make up the constructs, it is necessary to consider the adjustment indices, which have reference values shown in Table 4 together with the values obtained for The Brand Resonance Model.

Table 4

Adjustment Indices for the Brand Resonance Model

\begin{tabular}{c|c|c}
\hline Adjustment Measure & $\begin{array}{c}\text { Brand Resonance Obtained } \\
\text { Value }\end{array}$ & Default Value \\
\hline Qui-square $\left(X^{2}\right)$ & 543.37483 & Not defined \\
\hline p-value & 0.0000 & Higher than 0.05 \\
\hline Freedom degree $(d f)$ & 203 & The highest possible above zero \\
\hline$\left(X^{2} / d f\right)$ & 2.67672 & $\begin{array}{c}\text { Above } 1 \text { until } 3 \text { and to complex } \\
\text { models until } 5\end{array}$ \\
\hline GFI (Goodness Fit Index) & 0.77947 & Above or equal 0.90 \\
\hline $\begin{array}{c}\text { RMSEA (Root mean square half } \\
\text { approach) }\end{array}$ & 0.08652 & Above 0.03 and below 0.08 \\
\hline
\end{tabular}

Source: research data and Hair et al. (2009)

From the Table 4 results, it can be seen that only the $X^{2} / d f$ value was presented within the desired parameters. The RMSEA value presented a value close to the reference value and the GFI and the value of $X^{2}$ presented results that were farther from the reference values.

\section{Final considerations}

This research results corroborate with the Brand Resonance Model (Keller, 1993), which, as already described, implies a series of steps to create and maintain a strong brand through brand resonance. Thus, the Brand Resonance Model has nomological validity and the sequence of the items that form the nomological chain has statistical significance. The psychometric tests 
presented good values in general terms regarding to the constructs and their respective indicators.

The obtained results are partially similar to the ones obtained by Gautam and Kumar (2012), Aziz and Yasin (2010) and Yasin and Aziz (2010). Although these authors did not perform the SEM and only performed a linear regression whose dependent variable was the brand resonance, these studies concluded that the Brand Resonance Model is actually formed by the steps defined in its theory.

These studies theoretical contributions are pertinent to the Brand Resonance Model's validation (Keller, 1993), as well as to the Portuguese data collection instrument, since no similar studies have been found in Brazil and Portugal. In addition, other studies on the Brand Resonance Model are aimed at banking institutions such as Sandhe (2016), Gautam and Kumar (2012), Aziz and Yasin (2010) and Yasin and Aziz (2010), contrary to the brand equity study of the Gran Lord Hotel. Contrary to what have been done in the other studies already - where correlations used and a linear regression with the dependent variables and the other five constructs forming the independent variables - the SEM was used to perform a confirmatory factor analysis, representing the sequence of steps in the Brand Resonance Pyramid by a nomological chain means. The study by Choudhury and Kakati (2014) also used SEM, but considered all constructs directly related to brand resonance, which does not represent the emotional and rational paths present in the Brand Resonance Pyramid.

These studies practical implications are manifold. From the Brand Resonance Model it is verified that a strong brand development includes a series of activities that aim to strengthen each of the other five antecedent constructs - salience, performance, image, judgment and feeling - and present on the brand resonances' nomological chain. Thus, strong brand awareness and recognition created through well-defined communication activities are prerequisites for good brand management. In addition, creating the brands' positive image through appropriate associations and consequently positive feelings consolidation are key elements for the brand resonance development. They represent the emotional path within the Brand Resonance Pyramid. The rational path consists of services and products performance - represented by the brand - consistent with the positioning and promises branded, which influence the consumers judgment about the brand. A positive judgment on the customers part, according to the theory present in the Brand Resonance Model and according to the data obtained is essential for the maintenance and brand development. 
In addition, the Brand Resonance Model can be considered a valuable tool for managers to manage their brands. A practical considerations number is shown of how each of the constructs that lead to brand resonance can be strengthened. Thus, it can be considered a useful contribution in the brand management terms and be a reference for the strengthening these brands process. In addition, from the brand resonance's measurement, has an important indicator regarding the level of the brand's relationship with its customers. It is also necessary to consider that this brand resonance indicator is also composed by five other constructs (salience, image, performance, feeling and judgment), which can also be measured separately, increasing the level of detail about the follow-up of the customer's' perception

Regarding this studies' limitations, it should be noted that the sample was not randomly composed regarding to the Gran Lord Hotel guests, which is a limiting factor in terms of the results' generalization. In addition, it is also important that since most of the respondents were approach in the hotel restaurant, there is the possibility of generating some sort of bias in the answers due to the evaluation bringing great importance to the restaurant rather than evaluating the whole hotel. Also for the reason that not all the hotel guests attend the restaurant, which may limit the opinions variety on the Gran Lord Hotels' brand resonance.

Future studies could address a number of issues in order to improve the data collection instrument, and perhaps make the model more parsimonious, which would greatly help managers to apply a smaller data collection tool as well how to further improve the scales used psychometric characteristics, notably in discriminant validity terms, as well as to improve the SEM adjustment indexes. So, can indicators still be improved to represent the dimensions of the Brand Resonance Pyramid? Existing dimensions that have a causal relationship, such as image and feeling; and performance and judgment could each be replaced by only one dimension?

Another item to be highlight in services terms would be the service type. Thus, services related to entertainment, leisure, tourism and others alike could present different values in the rational path and emotional path terms in the Brand Resonance Pyramid compared to services related to a higher risk such as banking services, medical services, attorney services and other similar ones?

\section{References}


Adrian, S. (2014). An empirical study of the car modification market. (Master in marketing, Umeå School of Business and Economics, Umeå, Sweden).

Ahrens, A. R. V. (2016). Imaging place: interpreting place identity through consumer marketing techniques for non-profit, community development and business improvement organizations. (Master in Historic Preservation, University of Pennsylvania, Philadelphia, United States).

Aziz, N. A., \& Yasin, N. M. (2010). Analyzing the brand equity and resonance of banking services: Malaysian consumer perspective. International Journal of Marketing Studies, 2(2), 180-189.

Baird, M. D. (2015). Effects of product prototypicality on brand resonance in brand extensions. (Doctorade in Marketing, Curtin Business School, Bentley, Australia).

Bastos, D. H., Moura, L. R. C., \& Christino, J. M. M. (2015). Brand Equity da Usiminas: um estudo no setor siderúrgico brasileiro de aços planos. Gestão e Sociedade, 8(20), 688-713.

Choudhury, S., \& Kakati, R. P. (2014). An analytical study of spillover effect of different branding elements on customer-based brand equity. IUP Journal of Brand Management, 11(1), 30-46.

Farhana, N., \& Islam, S. (2012). Analyzing the brand equity and resonance of banking services: Bangladeshi consumer perspective. World Review of Business Research, 2(4), 148-163.

Fornell, C., Johnson, M. D., Anderson, E. W., Cha, J., \& Bryant, B. E. (1996). The American customer satisfaction index: nature, purpose, and findings. the Journal of Marketing, 60(4), 7-18.

Gautam, V., \& Kumar, M. (2012). An empirical investigation to analyze the brand equity and resonance of banking services: evidence from India. Management, 7(1), 3-16.

Hair Jr., J. F., Black, W. C., Babin, B. J., Anderson, R. E., \& Tathan R. L. (2009). Multivariate data analysis. Upper Saddle River: Prentice Hall.

Keller, K. L. (1993). Conceptualizing, measuring, and managing customer-based brand equity. Journal of Marketing, 57(1), 1-22.

Keller, K. L. (2001). Building customer-based brand equity. Marketing Management, 10(2), 14-19.

Keller, K. L. (2016). Reflections on customer-based brand equity: perspectives, progress, and priorities. AMS Review, 6(1-2), 1-16.

Malhotra, N. K. (2013). Marketing research: an applied orientation. Upper Saddle River: Prentice Hall. 
Márkus, A., \& Fallmyr, J. (2014). Framing the brand. (Doctorade in Strategy, Organization, Leadership, Copenhagen Business School, Copenhagen, Denmark).

Morgan, A., \& Griego, V. (1998). Easy use and interpretation of SPSS for windows: answering research questions with statistics. New Jersey: Lawrence Erlbaum Associates.

Moura, L. R. C., Ferreira, P. R., de Oliveira, A. D., de Moura, L. E. L., \& da Silveira Cunha, N. R. (2017). Avaliação do brand equity de uma instituição de ensino superior por meio da ressonância de marca e seus componentes. Desenvolve Revista de Gestão do Unilasalle, 6(2), 93-111.

Nunnaly, J. C., \& Bernstein, I. H. (1994). Psychometric theory. New York: McGraw-Hill.

Raut, U. R. (2015). Analysis of brand resonance amongst young consumers with reference to select product categories. (Doutorado em administração e gestão de negócios, Universidade do Porto, Porto, Portugal.

Rosenberger III, P. J. (2007). Brand trust: an Australian replication of a two-factor structure. Australian and New Zealand Marketing Academy (ANZMAC).

Sandhe, A. A. (2016). An exploratory study of brand equity of a commercial bank in Vadodara, India. Independent Journal of Management \& Production, 7(2), 289-302.

Storm, M. (2015). Factors influencing involvement, brand attachment and brand loyalty on Facebook brand pages. (Master in EBA, Branding and Communications Management, Copenhagen Business School, Copenhagen, Denmark.

Tri, H. M. (2014). Branding implementation of SMEs in Vietnam. Case: Alpine Creative Ltd. (Doctorade in International Business, Saimaa University of Applied Sciences. Lappeenranta, Finland).

Tsai, T. T.-H., Lin, A. J., \& Li, E. Y. (2014). The effect of philanthropic marketing on brand resonance and consumer satisfaction of CSR performance: does media self-regulation matter? Chinese Management Studies, 8(3), 527-547.

Verma, P. (2012). Analysis of brand equity and resonance of private banking services in India. Pacific Business Review International, 5(9), 59-66.

Yasin, N. M., \& Aziz, N. A. (2010). Determinants of brand equity of services: a verification approach in the banking industry in Malaysia. Asean Marketing Journal, 2(2), 27-34. 